\title{
ENHANCING THE SEISMIC RESPONSE OF A MULTIFUNCTIONAL STADIUM EQUIPPED WITH LRB ISOLATORS UNDER NEAR-FIELD EARTHQUAKES
}

Scientific paper / Znanstveni rad

Ali Vatanshenas

(Received: 10 October 2018; accepted: 28 November 2018)

Islamic Azad University Central Tehran Branch, Faculty of Civil Engineering, Iran, Master of Science

Corresponding author: a.vatanshenas@gmail.com

Davood Sharif Bajestany

Islamic Azad University Central Tehran Branch, Faculty of Civil Engineering, Iran, Master of Science

Misagh Hajihoseinloo

Islamic Azad University West Tehran Branch, Faculty of Civil Engineering, Iran, Master Student

Arian Aghelfard

Islamic Azad University Central Tehran Branch, Faculty of Civil Engineering, Iran, Master Student

\begin{abstract}
Disasters have always coexisted with civilization, and it is impossible to prevent earthquakes from occurring; however, it is possible to reduce the effects and decrease the loss of life, as well as injuries and damage to structures and infrastructure facilities. Investigating the safety of crowded places, such as stadiums, where many people gather for special events is of utmost importance. One of the most effective methods to counter an earthquake's force is the use of seismic isolators. Therefore, the seismic performance of a multifunctional stadium with and without lead rubber bearings (LRBs) during near-field earthquakes was studied in this research. It was found that the seismic isolators dissipated the input earthquake energy, and the isolated stadium received less base shear force and drift during the earthquake. It was observed that adding seismic isolators to the stadium had a significant positive effect on its behavior, and this technique is highly recommended to ensure residents' safety in near-field regions.
\end{abstract}

Keywords: lead rubber bearing; near-field earthquakes; nonlinear time history analysis; steel structures; seismic isolation; vibration control

\section{POBOLJŠANO POTRESNO PONAŠANJE VIŠENAMJENSKOG STADIONA S ELASTOMERNIM LEŽAJEVIMA PRI POTRESIMA S PLITKIM ŽARIŠTEM}

Sažetak: Katastrofe su oduvijek bile prisutne tjekom razvoja civilizacija pa je i nastanak potresa nemoguće spriječiti, ali je moguće smanjiti učinke potresa: smanjit ozljeđivanje i smrtnost ljudi te oštetjjivost konstrukcija i infrastrukturnih objekata. Izrazito je važno istražit sigurnost napučenih objekata kao što su stadioni, gdje se ljudi okupljaju u vrijeme posebnih događaja. Među najučinkovitjjim metodama za smanjenje sila potresa je uporaba izolatora. Stoga je u ovom istraživanju provedena seizmička analiza višenamjenskog stadiona s i bez elastomernih ležajeva pri potresnom djelovanju s plitkim žarištem. Utvrđeno je da je uporabom elastomernih ležajeva došlo do disipacije energije potresa, te da je stadion s izolatorima imao manje poprečne sile i međukatne pomake tjekom potresa. Uočeno je također da dodavanje seizmičkih izolatora ima važan pozitivan učinak na ponašanje stadiona pri djelovanju potresa. Ova se metoda preporučuje kako bi se osigurala sigurnost stanovnika u područjima s čestim potresima s plitkim žarištima.

Ključne riječi: elastomerni ležajevi; potresi s plitkim žarištem; nelinearna analiza zapisom potresa u vremenu; metalne konstrukcije; izolacija od potresa; kontrola vibracija

Vatanshenas, A, Sharif Bajestany, D, Hajihoseinloo, M, Aghelfard, A 


\section{INTRODUCTION}

There are a variety of techniques, such as using dampers and increasing the strength and stiffness of structural elements, to resist an earthquake's input energy to the structure, but the most effective way to mitigate earthquake force and ensure residents' safety is the use of seismic isolators. Some previous studies related to this research are discussed here. The effect of wind on the roof of the Montreal Olympic Stadium was investigated using a wind tunnel experiment [1]. The UC Berkeley California Memorial Stadium, located in a seismically hazardous area, was rehabilitated by researchers [2]. Vibration control of stadiums is another aspect of studies in this field, and it mostly focuses on the serviceability of stadiums [3-6]. The influence of crowds on the structural characteristics of a stadium was also determined in previous research [7]. In addition, the crowd movement on the dynamic outputs of a football stadium have been investigated $[8,9]$.

Adding dampers and seismic isolators to existing structures improves their performance under near-field ground motions [10-12]. Using seismic isolation systems is the best way to face earthquake forces among all other passive control systems. Therefore, this technique was used in this study to resist near-field ground motions. The seismic behavior of isolators under horizontal and vertical excitations have been studied [13]. Besides the conventional seismic isolation systems, such as lead rubber bearings (LRBs) and friction pendulum isolators, new base isolation systems, such as telescopic columns, have been introduced by researchers to mitigate the seismic responses of tall structures [14]. The use of different passive control systems in medium and high-rise structures with hybrid structural systems have been investigated [15]. The effect of coupled vertical and horizontal excitations on the behavior of modern reinforcement concrete moment-resisting frames (RC-MRFs) has been studied [16]. The fragility of RC-MRFs has also been evaluated under horizontal and vertical seismic motions that occur at the same time [17].

Near-field ground motions are common to occur in such seismically active regions as Iran, where the model considered in this study is located. Therefore, the near-field records have been selected for this study to determine the behavior of structures situated in places where near-field earthquakes are likely to occur. Many researchers have focused on the mitigation of the seismic responses of such ordinary structures as residential buildings and bridges and have neglected the importance of reducing the structural responses of stadiums. The lack of references related to decreasing the responses of stadiums was the motivation for this study.

\section{LEAD RUBBER BEARINGS}

Seismic isolation means separating the whole or part of a structure from the ground to reduce the acceleration applied to the structure. There are two types of seismic isolator: elastomeric and sliding bearings [18]. LRBs, which are one of the types of elastomeric bearing, are used in this study on the considered stadium. LRB isolators are one of the most common bearings used in different types of structures, including buildings and bridges [19]. As shown in Figure 1, LRBs are made out of rubber layers, reinforcing steel plates and a lead core. Steel plates force the lead plug to yield and deform under shear forces and dissipate the input energy [20-22].

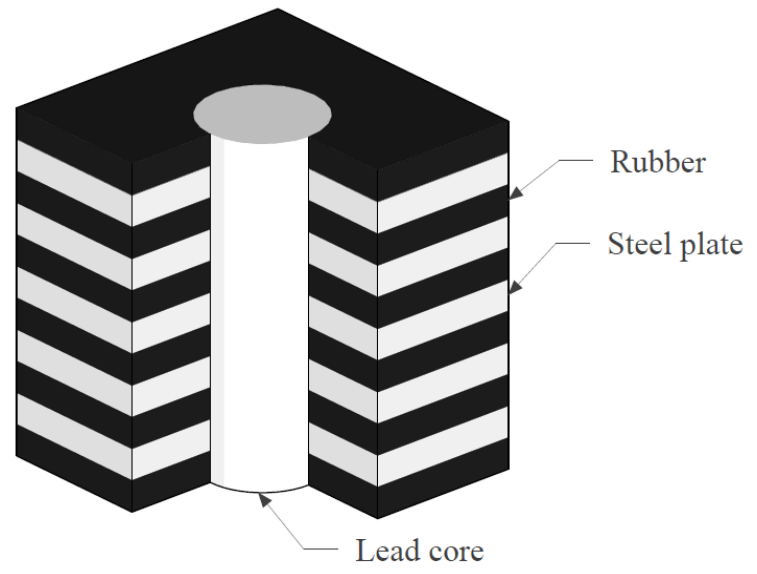

Figure 1 LRB components

Vatanshenas, A, Sharif Bajestany, D, Hajihoseinloo, M, Aghelfard, A 
Selected properties of the LRB isolators used in this study are the same as the ones used in other research [23] in which the behavior of a 10-story steel structure seismically isolated by LRB isolators was investigated. These LRB isolators were selected in this study because their modeling was verified in previous research studies [23]. Figure 2 illustrates the hysteresis diagrams of a single LRB isolator in the 10-story steel structure that were obtained previously [23] and by the authors of the present work. The comparison of these two diagrams shows a suitable similarity between the hysteresis behaviors. The LRB properties used in the prior study [23] are presented in Table 1 , and Figure 3 illustrates the yield force, initial, and effective stiffness parameters of a single isolator in a bilinear force-displacement diagram.

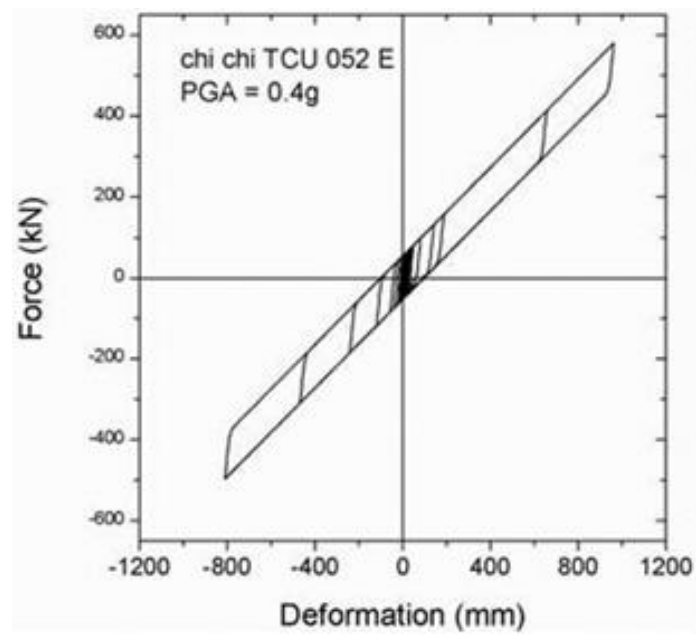

(a)

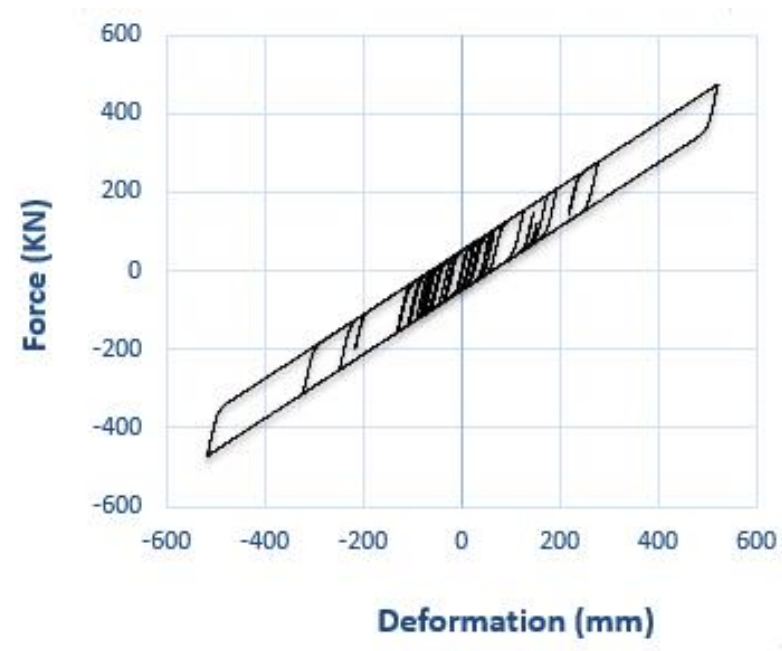

(b)

Figure 2 Hysteresis diagram obtained elsewhere [23] (a) and hysteresis diagram obtained in this study (b)

Table 1 LRB properties

\begin{tabular}{cc}
\hline Characteristics & Values \\
\hline vertical stiffness $(\mathrm{kN} / \mathrm{m})$ & 200687 \\
yield force $(\mathrm{kN})$ & 59.61 \\
effective damping & 0.1 \\
initial stiffness $(\mathrm{kN} / \mathrm{m})$ & 5419 \\
effective stiffness $(\mathrm{kN} / \mathrm{m})$ & 713
\end{tabular}

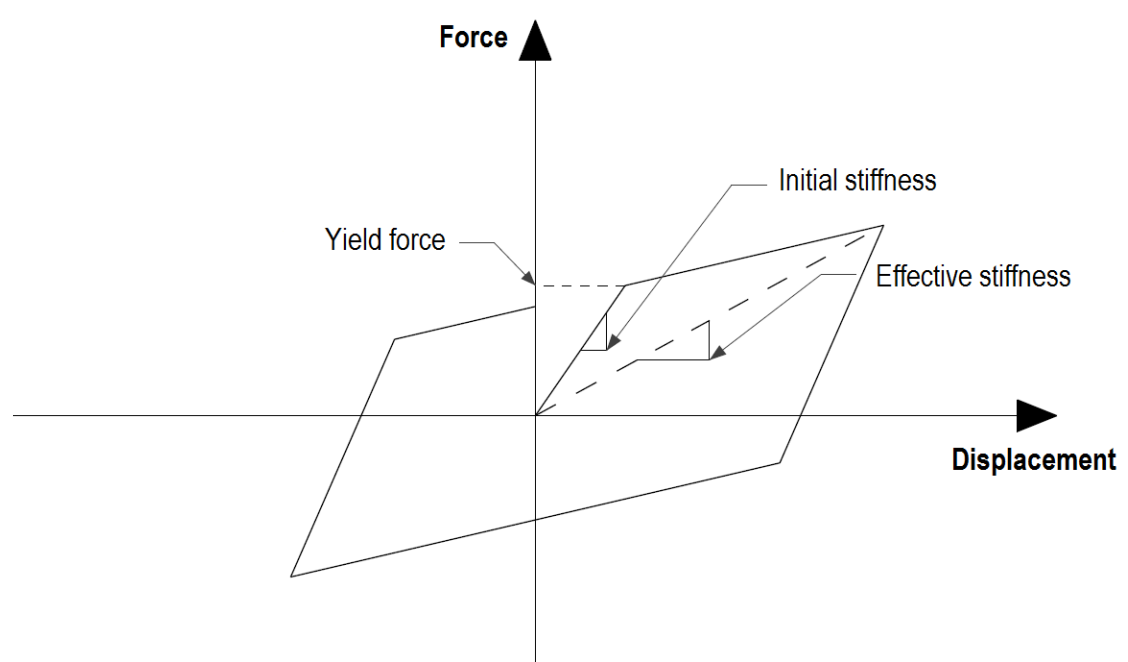

Figure 3 Force-displacement diagram of a single LRB

Vatanshenas, A, SharifBajestany, D, Hajihoseinloo, M, Aghelfard, A 


\section{NEAR-FIELD EARTHQUAKES}

Earthquakes are divided into two main groups: near-field and far-field earthquakes. In some cases, near-field earthquakes can be more destructive than far-field earthquakes, because this type of ground motion is closer to the epicenter, carries richer frequency contents, and has special characteristics that separate it from far-field earthquakes [24-26]. Near-field earthquakes may cause higher responses compared with far-field earthquakes with the same peak ground acceleration (PGA) [27]. Therefore, investigating the seismic behavior of different types of structure during near-field earthquakes seems necessary. In time history analysis, the lateral excitations applied to the structure are strong ground motions. According to Iran's seismic design code [28], at least three earthquake records must be obtained to utilize the time history analysis, but, as shown in Figures 4-10, seven raw earthquake records related to two perpendicular horizontal directions of recorded accelerations are used in this research to receive more reliable results compared with the case where only three records are used. Selecting the earthquake records is the most important step in the time history analysis procedure because the structural responses are highly dependent on the input earthquake records in this type of analysis. As shown in Table 2, the lateral forces applied to the stadium are seven scaled near-field earthquakes, selected based on similar magnitude, shear wave velocity, distance from epicenter, and fault mechanism. Selected earthquake records should indicate the most probable ground motion that might happen in the future. Therefore, selected records are scaled based on the response spectrum introduced by Iran's seismic design code [28] to change the amplitude of the raw earthquake records to make these records similar to probable earthquakes that might occur in a highly active region with a shear wave velocity range of 375 to $750 \mathrm{~m} / \mathrm{s}$ in the last $30 \mathrm{~m}$ height of the site where the stadium was constructed. This is done in such a way that the average response spectrum of the selected earthquakes shown in Figure 11 places higher than the response spectrum (10\% lower values than the provision's spectrum are also allowed) obtained by the provision between the 0.2 and 1.5 times the fundamental period of the structure range (Figure 12).

Table 2 Selected earthquakes and their characteristics

\begin{tabular}{|c|c|c|c|c|c|c|c|c|}
\hline Event & Year & Station & Magnitude & Fault type & Rjb (km) & Vs $(\mathrm{m} / \mathrm{s})$ & $\begin{array}{l}\text { PGA } \\
\text { (g) }\end{array}$ & $\begin{array}{l}\text { Scale } \\
\text { factor }\end{array}$ \\
\hline Helena & & Carroll Colleae & 6.0 & ctrike clin & 2.07 & & 0.161 & 4.34 \\
\hline & & & & & & & 0.298 & 2.34 \\
\hline Mors & & de & & & 2 & & 0.423 & 1.65 \\
\hline alf & 198 & op - P & & & & & 0.166 & 4.21 \\
\hline & 199 & $\mathrm{CH}$ & 6 & & 37 & & 0.068 & 10.2 \\
\hline asso & 1978 & Naso & 0. & stri & 17.15 & 620.56 & 0.150 & 4.66 \\
\hline Parkfield & 2004 & Parkfield-Stone Corral 2E & 6.0 & strike slip & 5.23 & 566.33 & 0.157 & 4.45 \\
\hline
\end{tabular}
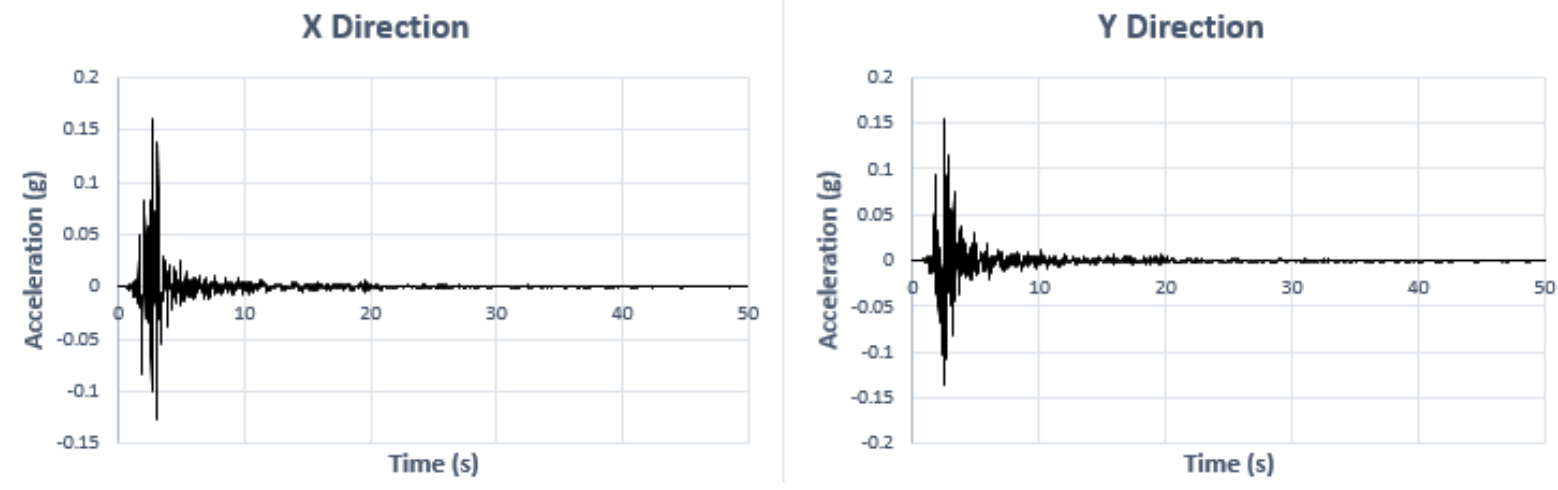

Figure 4 Acceleration time history diagrams of Helena earthquake 

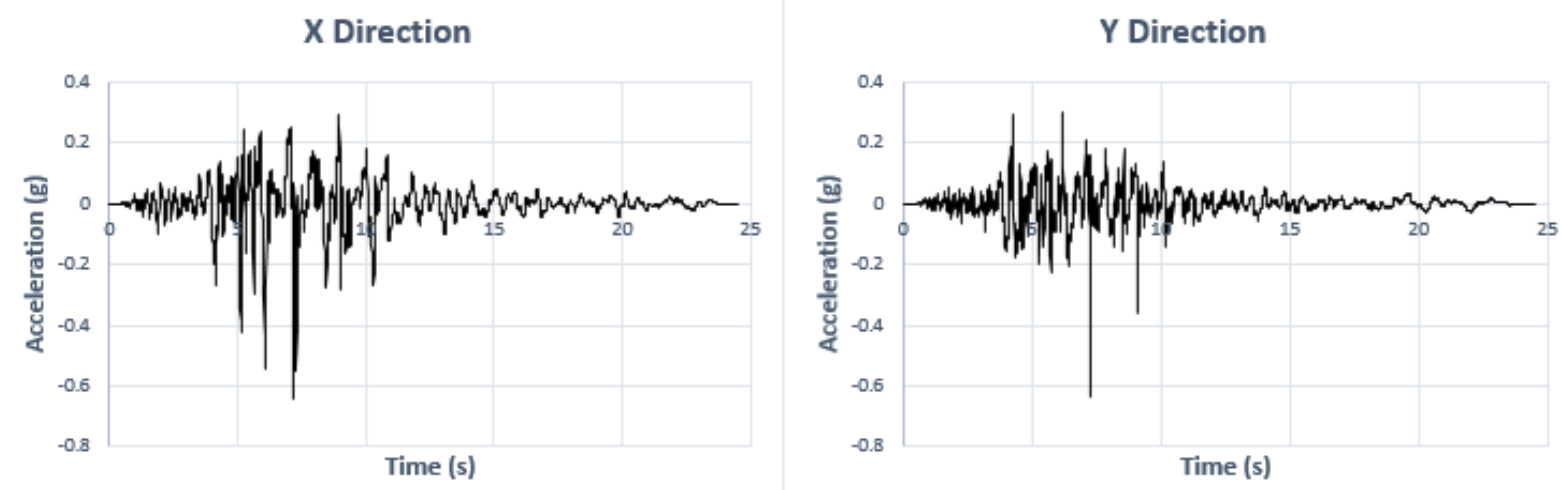

Figure 5 Acceleration time history diagrams of Victoria earthquake
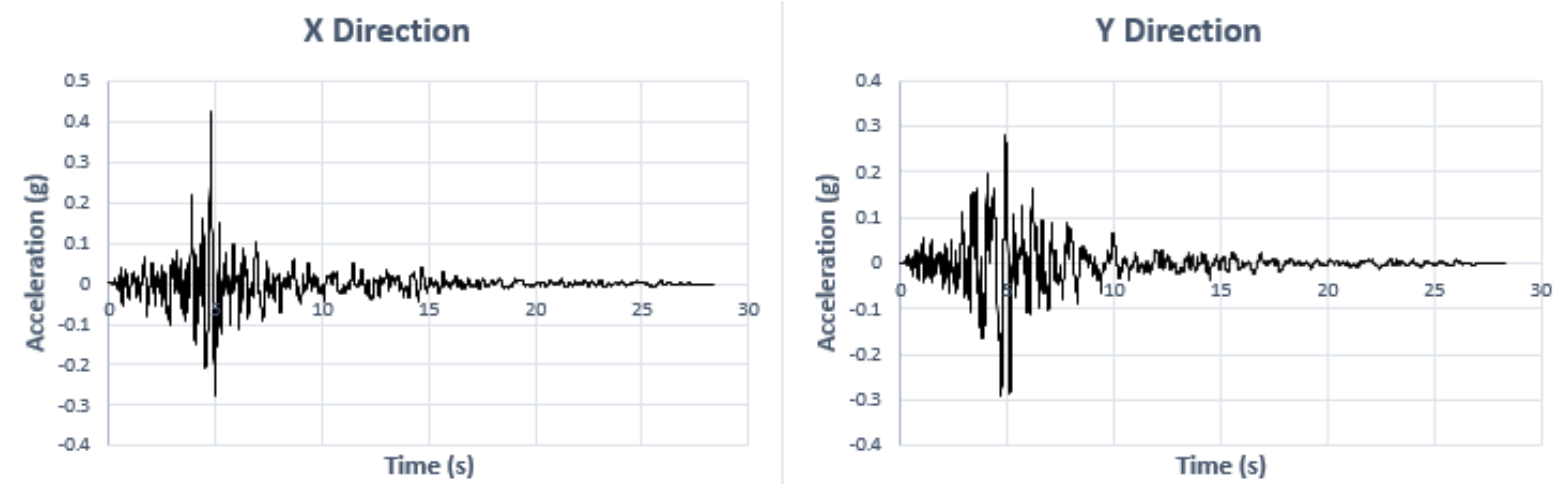

Figure 6 Acceleration time history diagrams of Morgan Hill earthquake
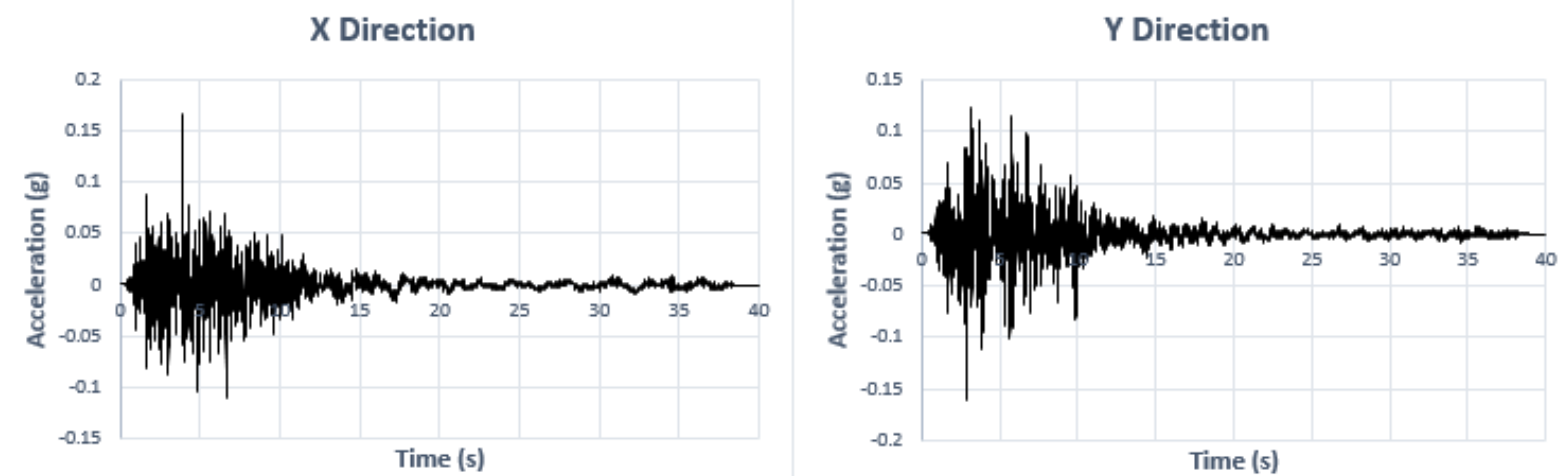

Figure 7 Acceleration time history diagrams of Chalfant Valley earthquake

X Direction

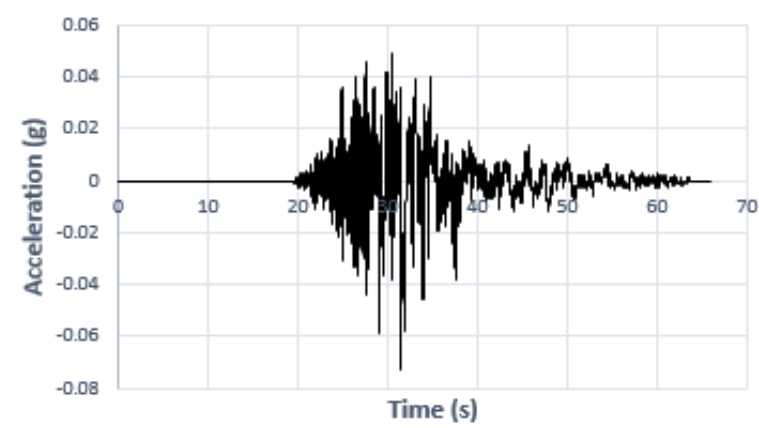

Y Direction

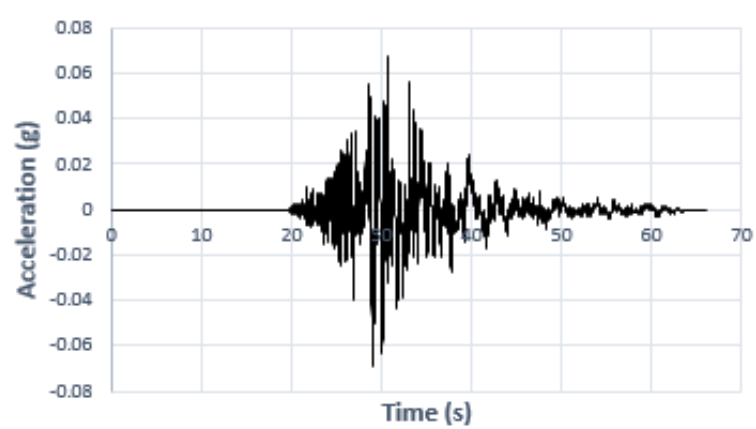

Figure 8 Acceleration time history diagrams of Chi-Chi earthquake

Vatanshenas, A, Sharif Bajestany, D, Hajihoseinloo, M, Aghelfard, A 

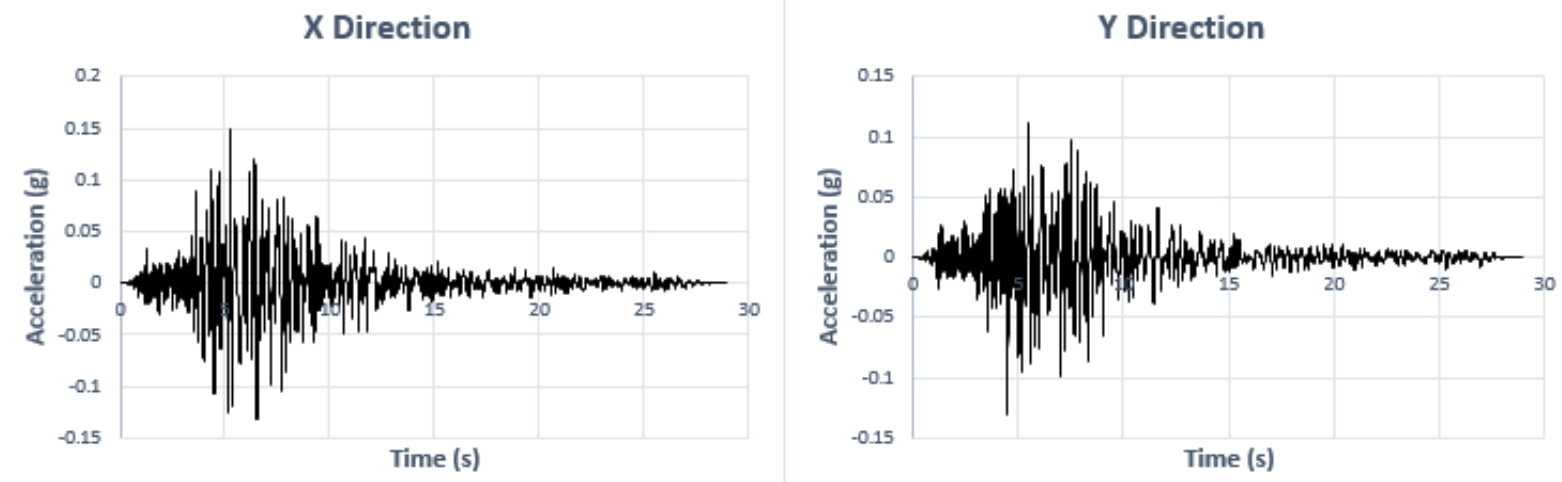

Figure 9 Acceleration time history diagrams Basso Tirreno earthquake
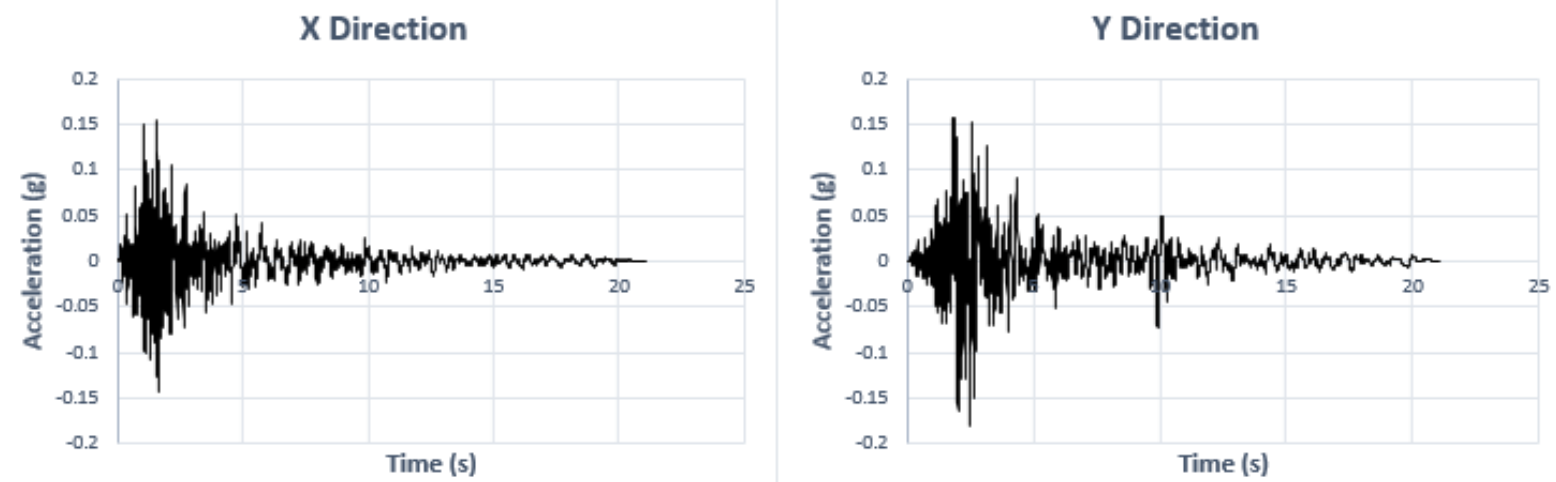

Figure 10 Acceleration time history diagrams of Parkfield earthquake

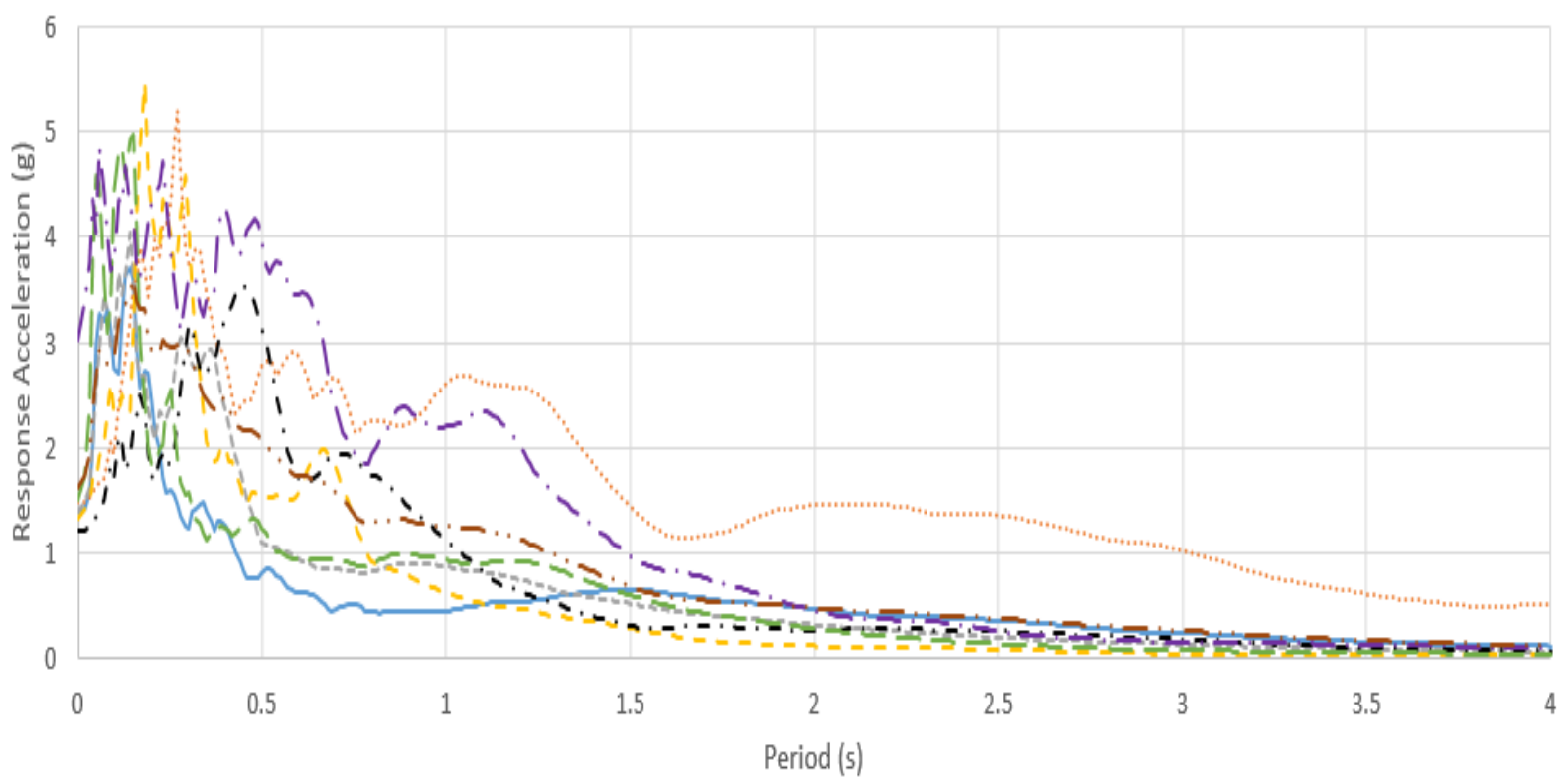

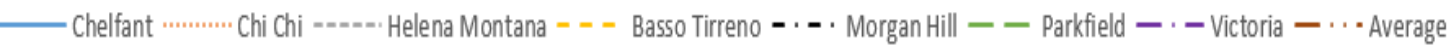

Figure 11 Spectral response accelerations and their average diagrams 


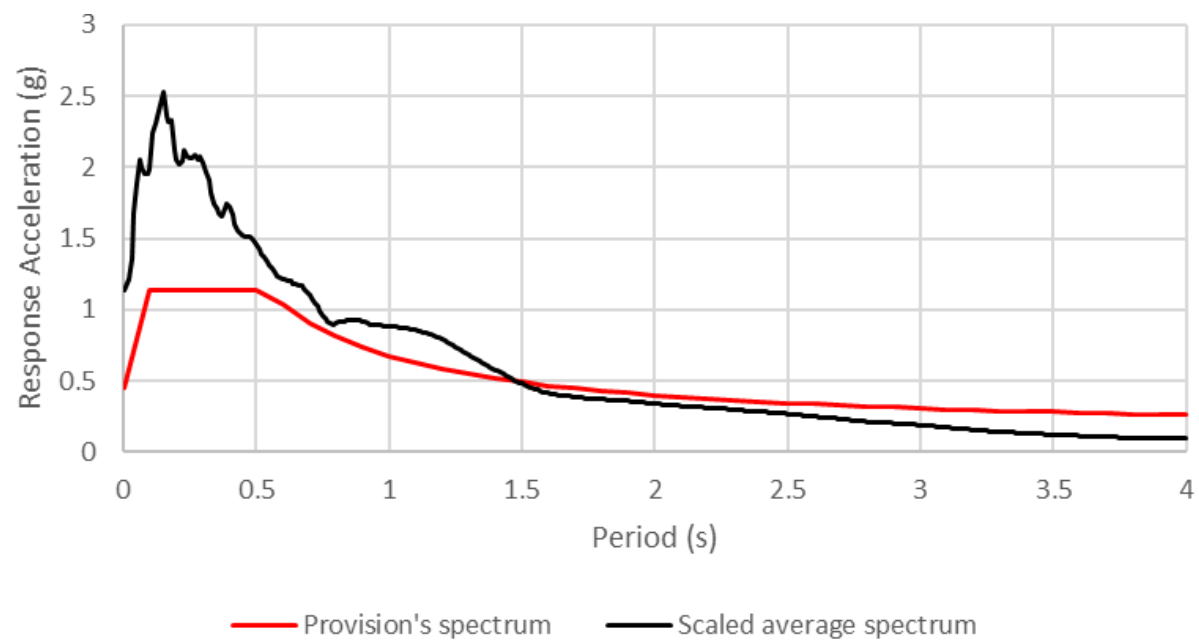

Figure 12 Scaled average spectrum based on provision's spectrum

\section{NUMERICAL MODEL}

Two steel moment frame multifunctional stadiums with the capacity of 3420 people, one with LRB isolators and the other one without them, have been modeled from beginning in a nonlinear platform. The stadium is designed under gravity and seismic loads according to AISC-LRFD93 regulation [29] and the frame elements are designed based on elastic linear behavior. Ninety-six LRB isolators have been used to isolate this stadium from the strong nearfield ground motions. The LRB isolators selected for the modeling have the properties used in the LRB section, which are the vertical siffness of $200687 \mathrm{kN} / \mathrm{m}$, yield force of $59.61 \mathrm{kN}$, effective damping of 0.1 , initial stiffness of $5419 \mathrm{kN} / \mathrm{m}$, and effective stiffness of $713 \mathrm{kN} / \mathrm{m}$. Equation 1 represents the effective stiffness of LRB isolators. In this equation $D, Q$, and $K_{2}$ are the isolator displacement, intercept of the hysteresis loop and force axis, and postyield stiffness, respectively. Equation 2 shows the effective damping of an LRB isolator that is dependent on the area of the hysteresis loop, effective stiffness, and isolator displacement. The three-dimensional and plan view of the stadium are illustrated in Figures 13 and 14, respectively. The connection between frame elements is assumed to be rigid, and the beam and column sections are shown in Figures 15 and 16, respectively. The dead and live loads of this structure are assumed to be 5 and $4.9 \mathrm{kN} / \mathrm{m}^{2}$, respectively. The first mode period of the fixed-base structure is $0.46 \mathrm{~s}$, and it changed to $1.01 \mathrm{~s}$ after adding the LRB isolators between the foundation and columns of the stadium. The increase of fundamental period is one of the main characteristics of base isolators that reduces the acceleration applied to the structure.

$\mathrm{K}_{\text {eff }}=\mathrm{K}_{2}+\mathrm{Q} / \mathrm{D}$

$\beta_{\text {eff }}=\left(\right.$ area of the hysteresis loop) $/ 2 \pi K_{\text {eff }} D^{2}$

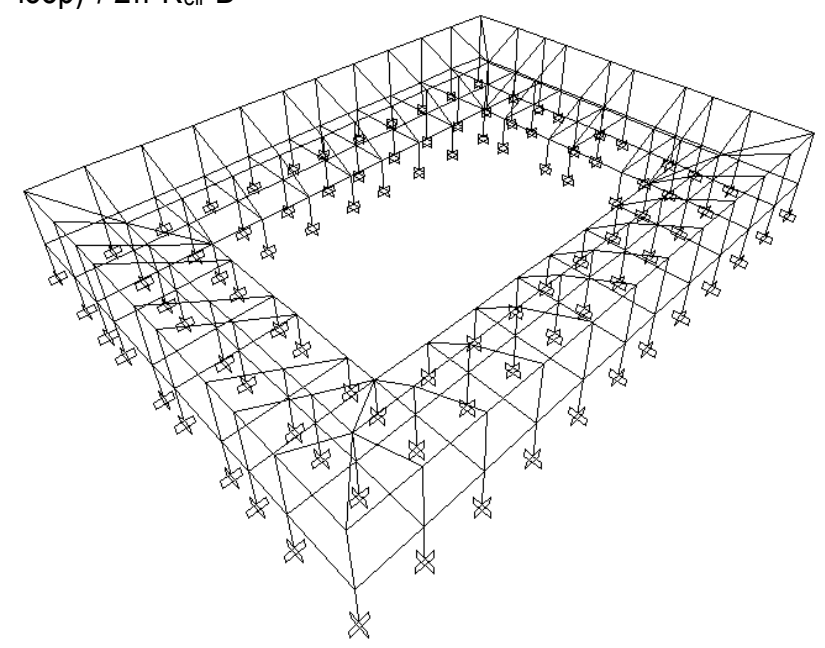

Figure 13 Three-dimensional model of the considered stadium

Vatanshenas, A, Sharif Bajestany, D, Hajihoseinloo, M, Aghelfard, A 


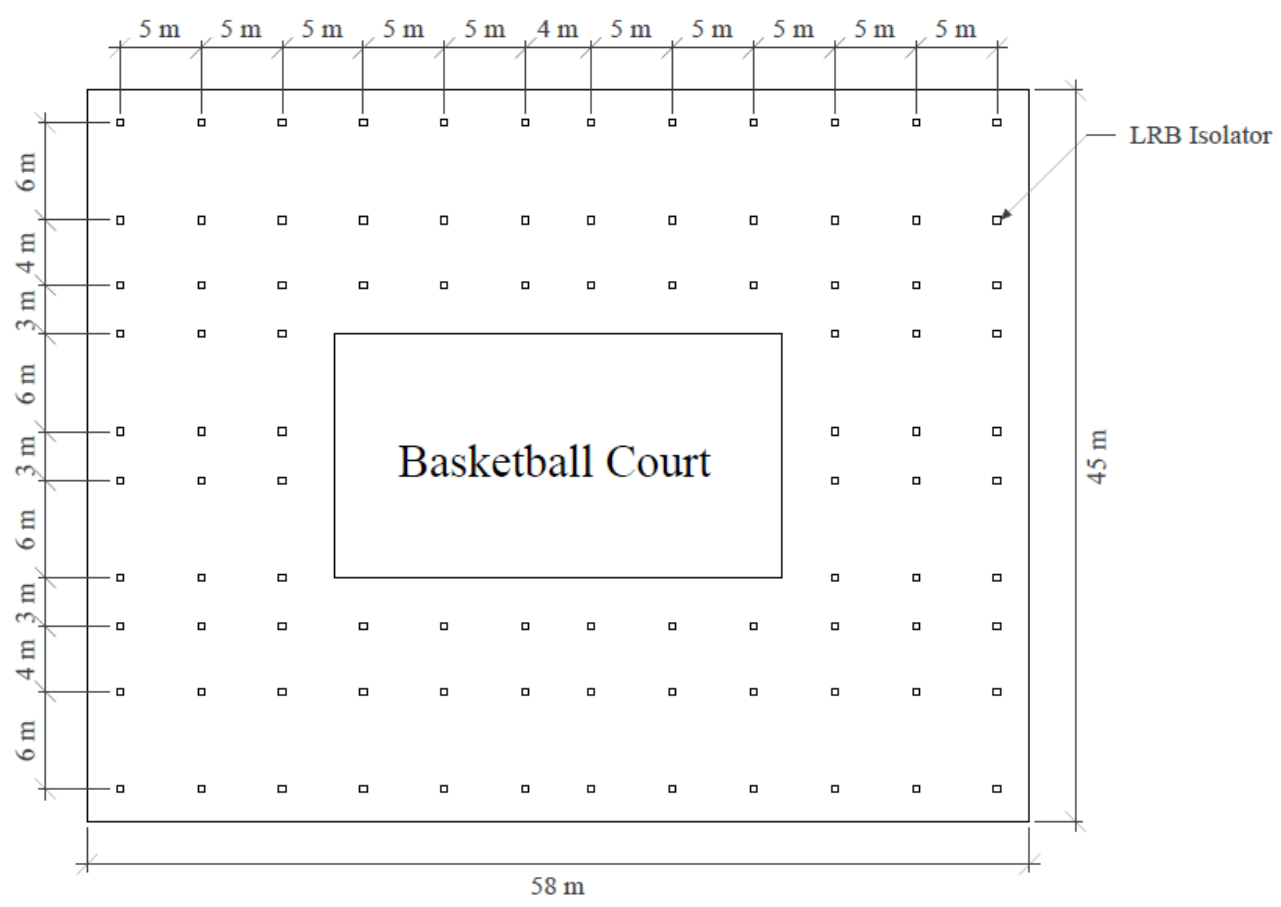

Figure 14 Plan view of the stadium above the foundation

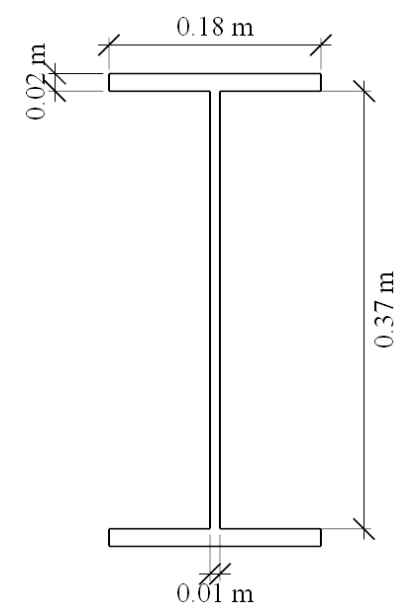

Figure 15 Beam section used in this study

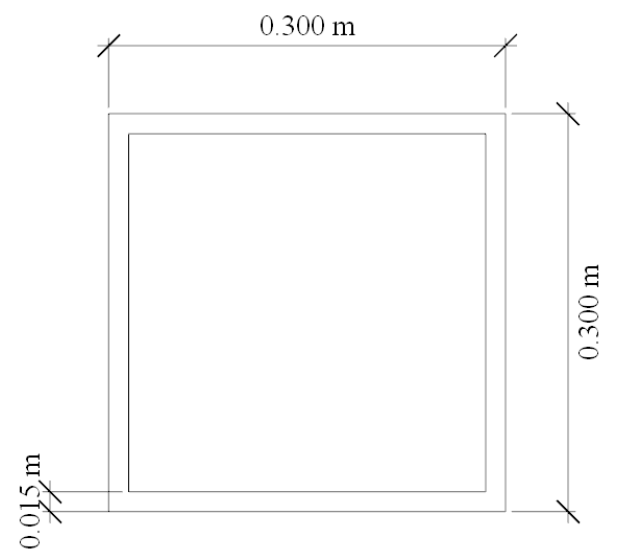

Figure 16 Column section used in this study

Vatanshenas, A, Sharif Bajestany, D, Hajihoseinloo, M, Aghelfard, A 


\section{TIME HISTORY ANALYSIS}

\subsection{COMPARISON BASED ON BASE SHEAR FORCE}

One of the main advantages of seismic isolators compared with other devices that increase the capacity of the structure is reducing the demand created by earthquakes. This means that the isolated structures will receive less input energy and base shear force in comparison with fixed-base structures. The base shear-force diagrams in two horizontal dimensions of the considered stadiums are compared with each other in Figures 17 and 18. As shown in these figures and Table 3, which indicates the maximum values of base shear forces, the fixed-base structure receives a significant amount of shear force, while the isolated stadium receives minor base shear force. According to Table 3, using seismic isolators can reduce more than half of the base shear force in some cases of earthquakes which is a considerable amount.

Table 3 Base shear force values for two stadiums during near-field earthquakes

\begin{tabular}{cccccc}
\hline Event & \multicolumn{2}{c}{ Fixed base } & \multicolumn{2}{c}{ Isolated base } & $\begin{array}{c}\text { Reduced } \\
\text { percentage (\%) }\end{array}$ \\
\cline { 2 - 5 } & $\begin{array}{c}\text { Maximum base } \\
\text { shear force (kN) }\end{array}$ & $\begin{array}{c}\text { Minimum base } \\
\text { shear force (kN) }\end{array}$ & $\begin{array}{c}\text { Maximum base } \\
\text { shear force (kN) }\end{array}$ & $\begin{array}{c}\text { Minimum base } \\
\text { shear force (kN) }\end{array}$ & \\
\hline Helena & 6280 & -6820 & 4880 & -4560 & 28.44 \\
Victoria & 13100 & -22100 & 7250 & -9730 & 55.97 \\
Morgan Hill & 13000 & -14800 & 6980 & -6860 & 52.83 \\
Chalfant Valley & 8670 & -8820 & 4400 & -4170 & 50.11 \\
Chi-Chi & 15700 & -15000 & 6800 & -8800 & 43.94 \\
Basso Tirreno & 14600 & -16000 & 6700 & -5880 & 58.12 \\
Parkfield & 7200 & -8740 & 5120 & -5500 & 37.07 \\
\hline
\end{tabular}
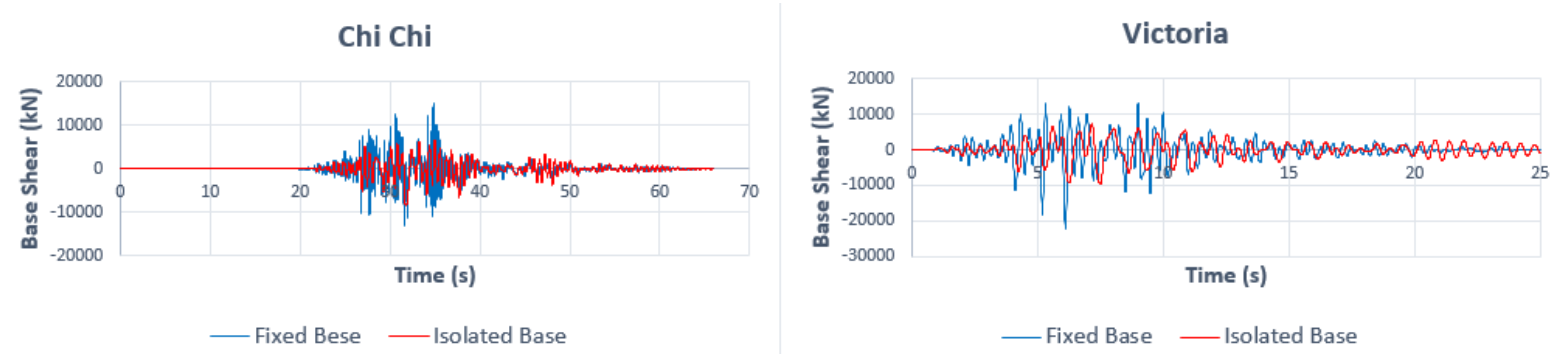

Figure 17 Comparison of base shear force of two stadiums along $X$-axis
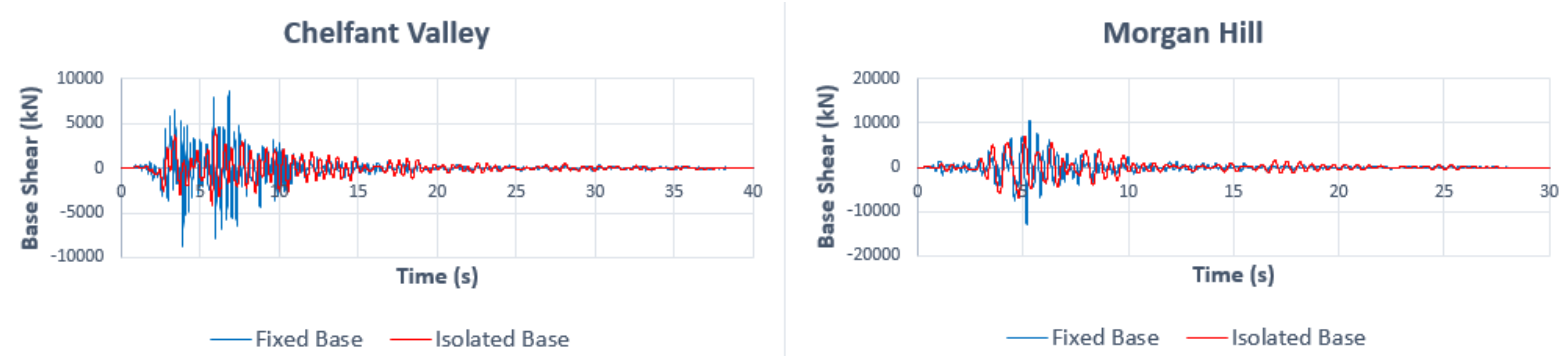

Figure 18 Comparison of base shear force of two stadiums along $Y$-axis

\subsection{COMPARISON BASED ON DRIFT}

In this section, the impact of using seismic isolators on the mitigating drit is investigated. Based on Iran's seismic regulation, dritt is the relative distance between two nodes at different heights divided by the vertical distance between those nodes in the considered structure. As illustrated in Figure 19, nodes 234 and 138 were selected for computing drift in this study. According to Table 4, the stadium that was isolated by LRB isolators had less drift compared with the fixed-base stadium. As shown in Figure 20, after LRB isolators were added to the base structure, 
Enhancing the seismic response of a multifunctional stadium equipped with LRB isolators under near-field earthquakes

the dritt significantly decreased over entire duration of the Morgan Hill and Helena earthquakes along the $X$ - and Y-directions.

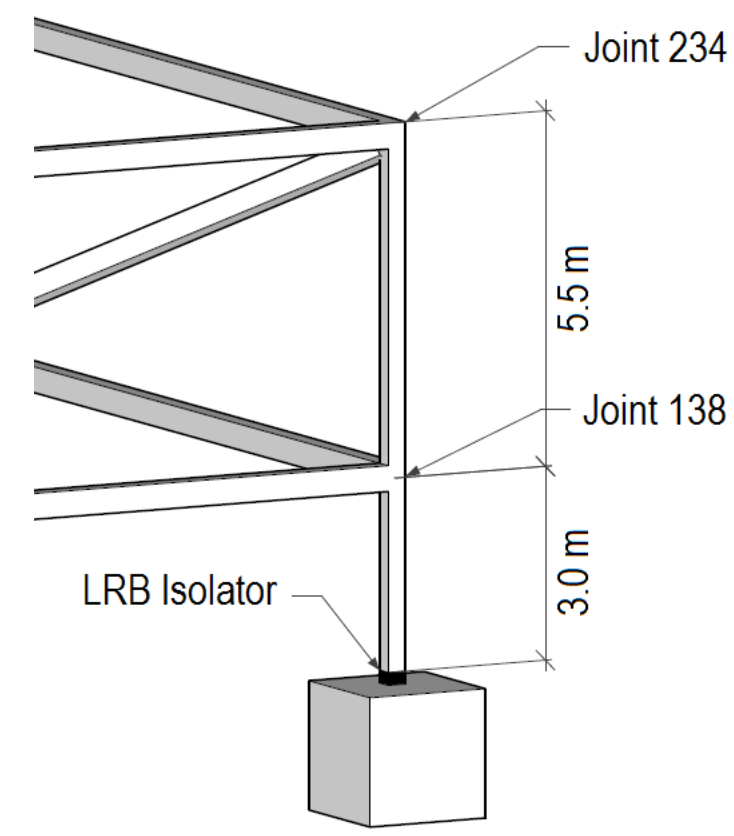

Figure 19 Considered nodes and the vertical distance between them

Table 4 Drift values for two stadiums during near-field earthquakes

\begin{tabular}{cccc}
\hline Event & Fixed base & Isolated base & $\begin{array}{c}\text { Reduced } \\
\text { percentage (\%) }\end{array}$ \\
\cline { 2 - 3 } & Maximum drift & Maximum drift & \\
\hline Helena & 0.00766 & 0.00339 & 55.74 \\
Victoria & 0.00927 & 0.00782 & 15.64 \\
Morgan Hill & 0.00871 & 0.00552 & 36.62 \\
Chalfant Valley & 0.00332 & 0.00246 & 25.90 \\
Chi-Chi & 0.00902 & 0.00683 & 24.27 \\
Basso Tirreno & 0.00882 & 0.00548 & 37.86 \\
Parkfield & 0.00381 & 0.00201 & 47.38 \\
\hline
\end{tabular}
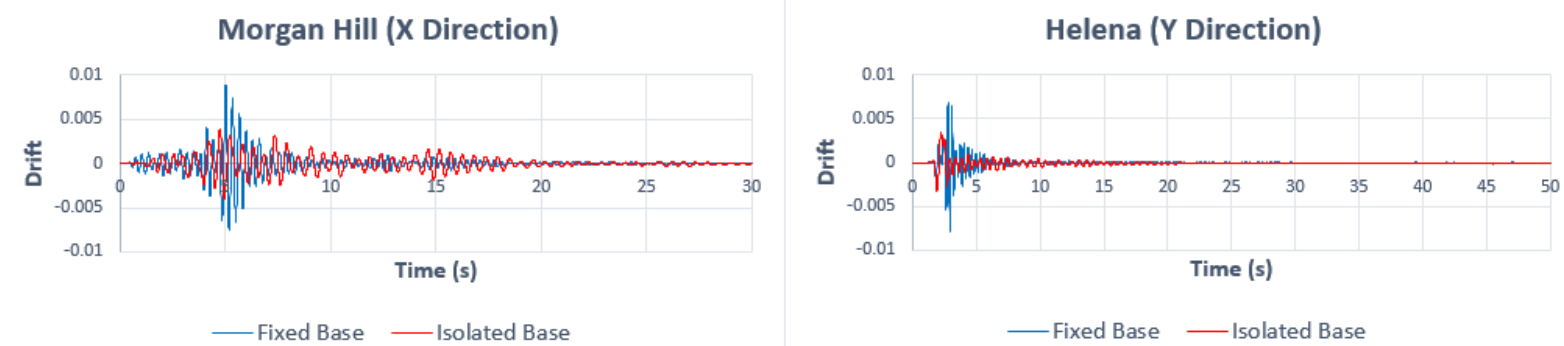

Figure 20 Comparison between the drift of the two stadiums along $X$-and $Y$-axis

\subsection{INVESTIGATING THE HYSTERESIS DIAGRAMS OF LRB ISOLATORS}

The behavior of LRB isolators can be inferred by investigating their base shear force-displacement or hysteresis diagrams. Figure 21 shows the performance of a single LRB isolator during the Basso Tirreno and Victoria earthquakes. The area under hysteresis diagram shows the amount of dissipated energy. It is indicated in these figures that this isolator performed well and absorbed the input energy of the mentioned earthquakes. 

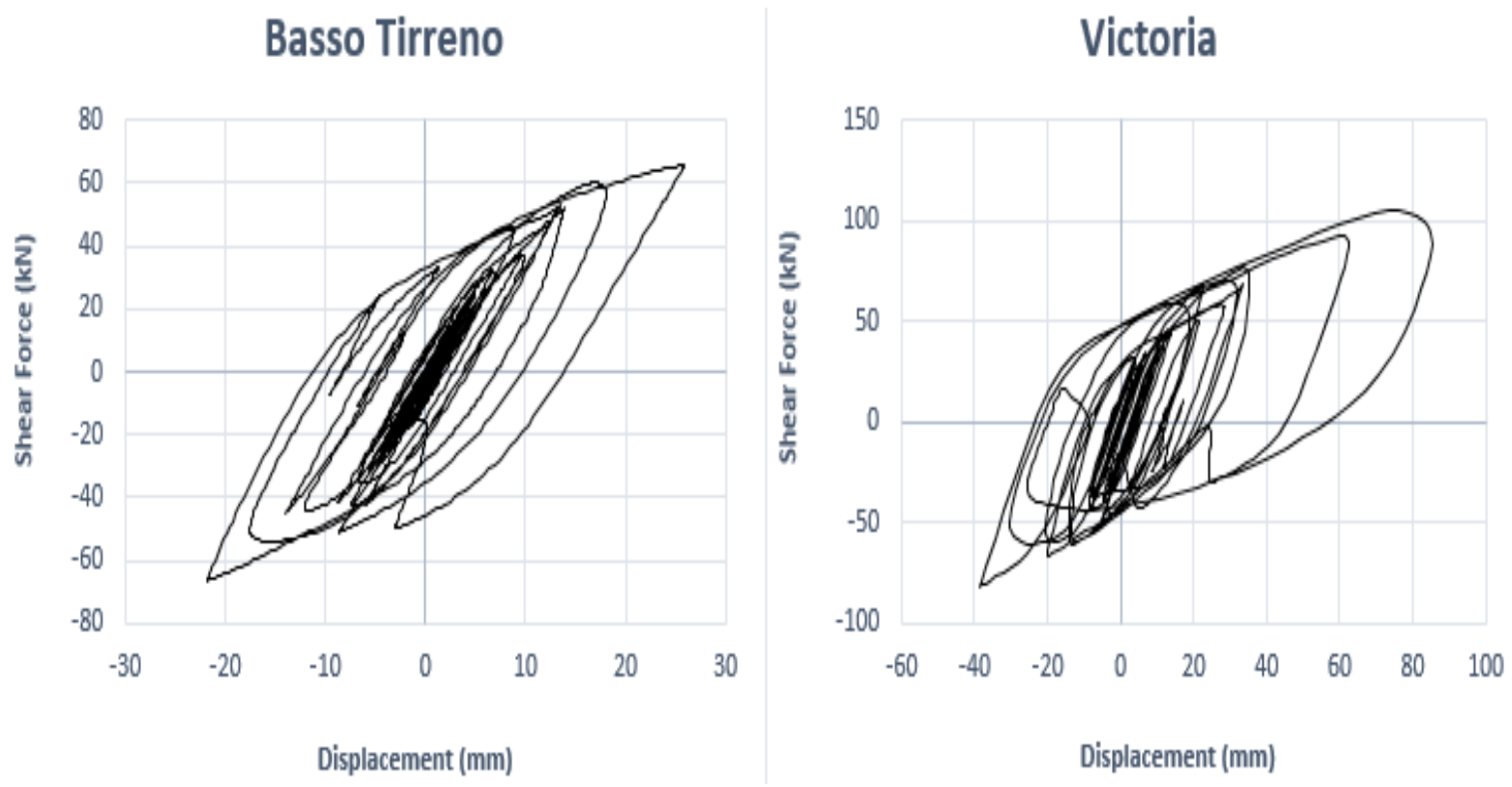

Figure 21 Hysteresis diagrams of a single LRB isolator under Basso Tirreno and Victoria earthquakes

\section{CONCLUSION}

Throughout this study, the seismic behavior of a multifunctional stadium with and without LRB isolators during nearfield earthquakes was investigated. The performance of the fixed-base structure was considerably improved by adding LRB isolators beneath the stadium. The seismically isolated structure received less base shear force, and its drift was lower than that of the fixed-base structure in all cases. Seismic isolators dissipated the earthquake energy and performed well during near-field earthquakes. It can be concluded that by using LRB isolators in the considered structure, such structural responses as base shear force and drift were decreased. It was also observed that the reduction amount of structural responses was different for selected earthquakes, which shows that the structural responses of the stadiums were dependent on the input lateral forces and their frequency contents. Only an accurate assessment can be obtained considering the nonlinear behavior of the frame elements. Investigating the seismic performance of stadiums equipped with friction pendulum bearings and a combination of elastomeric and friction isolators is suggested for further studies.

\section{References}

[1] Irwin, H.P. A. H.; Wardlaw, R. L. 1980: A wind tunnel investigation of a retractable fabric roof for the Montreal Olympic stadium, Proceedings of the Fifth International Conference, USA, 1979, pp. 925-938, https://doi.org/10.1016/B978-1-4832-8367-8.50087-5

[2] Vignos, R.; Walters, M.; Bomba, G.; Friedman, D. 2012: UC Berkeley's California memorial stadium seismic strengthening of an historic structure residing over an active fault, Proceedings of the 2009 ATC and SEI Conference on Improving the Seismic Performance of Existing Buildings and Other Structures, USA, 2009, pp. 1295-1304, https://ascelibrary.org/doi/10.1061/41084\%28364\%29119

[3] Caprioli, A.; Castellani, A.; Cigada, A.; Vanali, M. 2005: Vibration monitoring of the G. Meazza stadium in Milano during concerts and football matches, IMAC XXIII, USA, 2005, pp. 1-9

[4] Salyards, K. A.; Hanagan, L. M. 2007: Analysis of coordinated crowd vibration levels in a stadium structure, IMAC-XXV - Celebrating 25 Years of IMAC, USA, 2007

[5] Cigada, A.; Caprioli, A.; Redaelli, M.; Vanali, M. 2008: Vibration testing at Meazza stadium: Reliability of operational modal analysis to heath monitoring purposes, American Society of Civil Engineers (ASCE), 22 (4), pp. 228-237, https://ascelibrary.org/doi/10.1061/\%28ASCE \%290887-3828\%282008\%2922\%3A4\%28228\%29 
[6] Salyards, K. A.; Hanagan, L. M. 2010: Evaluation of vibration assessment criteria and their application to stadium serviceability, Journal of Performance of Constructed Facilities, 24 (2), pp. 100-107, https://ascelibrary.org/doi/10.1061/\%28ASCE\%29CF.1943-5509.0000088

[7] Reynolds, P.; Pavic, A.; Ibrahim, Z. 2004: Changes of modal properties of a stadium structure occupied by a crowd, IMAC XXII - The 22 ${ }^{\text {nd }}$ Conference on Structural Dynamics, USA, 2004

[8] Catbas, F. N.; Gul, M. 2009: Dynamic response monitoring and correlation to crowd movement at a football stadium, Proceedings of the IMAC XXII, USA, 2009

[9] Celik, O.; Catbas, N.; Tien Do, N.; Gul, M.; Abdeljaber, O.; Younis, A.; Avci, O. 2016: Issues, Codes and basic studies for stadium Dynamics, Proceedings of the Second International Conference on Infrastructure Management, Assessment and Rehabilitation Techniques, United Arab Emirates, 2016

[10] Vatanshenas, A.; Rohanimanesh, M. S.; Mohammadiha, E. 2018: Investigating the performance of viscoelastic dampers (VED) under near-field earthquakes with directivity feature, Civil and Environmental Engineering, 14 (1), pp. 21-27, https://doi.org/10.2478/cee-2018-0003

[11] Vatanshenas, A.; Tavakoli Moghadam, B. 2018: Determining the effect of adding greenhouse structure to a residential building using friction pendulum system (FPS) under near-field earthquakes, Energy and Environment Research, 8 (1), pp. 56-63, https://doi.org/10.5539/eer.v8n1p56

[12] Vatanshenas, A. 2017: Investigation of PTMD system affected by Parkfield near-field earthquake, Journal of Modern Applied Science, 11 (4), pp. 70-79, http://doi.org/10.5539/mas.v11n4p70

[13] Farsangi, E. N.; Tasnimi, A. A.; Yang, T. Y.; Takewaki, l.; Mohammadhasani, M. 2018: Seismic performance of a resilient low-damage base isolation system under combined vertical and horizontal excitations, Smart Structures and Systems, 22 (4), pp. 383-397, http://dx.doi.org/10.12989/sss. 2018.22.4.383

[14] Hosseini, M.; Farsangi, E. N. 2012: Telescopic columns as a new base isolation system for vibration control of high-rise buildings, Earthquakes and Structures, 3 (6), pp. 853-867, http://dx.doi.org/10.12989/eas.2012.3.6.853

[15] Farsangi, E. N.; Adnan, A. 2012: Seismic performance evaluation of various passive damping systems in high and medium-rise buildings with hybrid structural system, Gazi University Journal of Science, 25 (3), pp. 721735.

[16] Farsangi, E. N.; Tasnimi, A. A. 2016: The influence of coupled horizontal-vertical ground excitations on the collapse margins of modern RC-MRFs, International Journal of Advanced Structural Engineering (IJASE), 8 (2), pp. 169-192, http://dx.doi.org/10.1007/s40091-016-0122-0

[17] Farsangi, E. N.; Tasnimi, A. A.; Mansouri, B. 2015: Fragility assessment of RC-MRFs under concurrent vertical-horizontal seismic action effects. Computers and Concrete, 16 (1), pp. 99-123, http://dx.doi.org/10.12989/cac. 2015.16.1.099

[18] Taylor, A. W.; Igusa, T. 2004: Primer on seismic isolation, 1st Ed., American Society of Civil Engineers, Virginia

[19] Buckle I.G.; Mayes R.L. 1990: Seismic isolation: history, application and performance - a world review, Earthquake Spectra, 6(2), pp. 161-201, https://doi.org/10.1193/1.1585564

[20] Priestley, M. J. N.; Seible, F.; Calvi, G. M. 1996: Seismic design and retrofit of bridges, John Wiley and Sons, New York

[21] Skinner, R. I.; Robinson, W. H.; McVerry, G.H. 1993: An introduction to seismic isolation, John Wiley \& Sons, New York

[22] Naeim, F.; Kelly, J. 1996: Design of seismic isolated structures, 1st Ed., Wiley, New York

[23] Bhandari M.; Bhart S. D.; Shrimal, M. K.; Datta T. K. 2017: The numerical study of base-isolated buildings under near-field and far-field earthquakes, Journal of Earthquake Engineering, 22(6), pp. 989-1007, https://doi.org/10.1080/13632469.2016.1269698

[24] Cox, K. E.; Ashford, S. A. 2002: Characterization of large velocity pulses for laboratory testing, Pacific Earthquake Engineering Research Center, California

[25] Wang G. C.; Zhou P. Z.; lgel H. 2002: Characteristics of amplitude and duration for near fault strong ground motion from the 1999 Chi-Chi, Taiwan earthquake, Soil Dynamics and Earthquake Engineering, 22 (1), pp. 7396, https://doi.org/10.1016/S0267-7261(01)00047-1 
[26] Bertero V. V.; Mahin S. A.; Herrera R. A. 1978: Aseismic design implications of near-fault san fernando earthquake records, Earthquake Engineering \& Structural Dynamics, 6 (1), pp. 31-42, https://onlinelibrary.wiley.com/doi/abs/10.1002/eqe.4290060105

[27] Loh C. H.; Wan S.; Liao W. I. 2002: Effects of hysteretic model on seismic demands: consideration of nearfault ground motions, The Structural Design of Tall and Special Buildings, 11 (3), pp. 155-169, https://doi. org/10.1002/tal.182

[28] Iranian code of practice for seismic resistant design of buildings standard (4th ed.). 2015: Tehran

[29] American Institute of Steel Construction (AISC-LRFD93), United States of America

Please cite this article as:

Vatanshenas, A.; Sharif Bajestany, D.; Hajihoseinloo, M.; Aghelfard, A.: Enhancing the seismic response of a multifunctional stadium equipped with LRB isolators under near-field earthquakes, Electronic Journal of the Faculty of Civil Engineering Osijek-e-GFOS, 2018, 17, pp. 11-13, https://doi.org/10.13167/2018.17.2 
